\title{
Payment incentives for community-based psychiatric care in Ontario, Canada
}

\author{
David Rudoler PhD, Claire de Oliveira PhD, Joyce Cheng MSc, Paul Kurdyak PhD MD
}

Cite as: CMAJ 2017 December 11;189:E1509-16. doi: 10.1503/cmaj.160816

See related articles at www.cmaj.ca/lookup/doi/10.1503/cmaj.170092 and www.cmaj.ca/lookup/doi/10.1503/cmaj.171126

\begin{abstract}
BACKGROUND: In September 2011, the government of Ontario implemented payment incentives to encourage the delivery of community-based psychiatric care to patients after discharge from a psychiatric hospital admission and to those with a recent suicide attempt. We evaluated whether these incentives affected supply of psychiatric services and access to care.
\end{abstract}

METHODS: We used administrative data to capture monthly observations for all psychiatrists who practised in Ontario between September 2009 and August 2014. We conducted interrupted timeseries analyses of psychiatrist-level and patient-level data to evaluate whether the incentives affected the quantity of eligible outpatient services delivered and the likelihood of receiving follow-up care.

RESULTS: Among 1921 psychiatrists evaluated, implementation of the incentive payments was not associated with increased provision of follow-up visits after discharge from a psychiatric hospital admission (mean change in visits per month per psychiatrist 0.0099 , $95 \%$ confidence interval $[\mathrm{Cl}]-0.0989$ to 0.1206 ; change in trend $0.0032,95 \% \mathrm{Cl}-0.0035$ to 0.0095$)$ or after a suicide attempt (mean change $-0.0910,95 \% \mathrm{Cl}-0.1885$ to 0.0026 ; change in trend $0.0102,95 \%$ $\mathrm{Cl} 0.0045$ to 0.0159$)$. There was also no change in the probability that patients received follow-up care after discharge (change in level $-0.0079,95 \% \mathrm{Cl}-0.0223$ to 0.0061 ; change in trend $0.0007,95 \%$ $\mathrm{Cl}-0.0003$ to 0.0016 ) or after a suicide attempt (change in level $0.0074,95 \% \mathrm{Cl}$ -0.0094 to 0.0366 ; change in trend $0.0006,95 \% \mathrm{Cl}-0.0007$ to 0.0022 ).

INTERPRETATION: Our results suggest that implementation of the incentives did not increase access to follow-up care for patients after discharge from a psychiatric hospital admission or after a suicide attempt, and the incentives had no effect on supply of psychiatric services. Further research to guide design and implementation of more effective incentives is warranted.

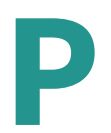

ay for performance has been employed by many jurisdictions to improve the delivery of evidence-based care, to expand access and to improve health outcomes. ${ }^{1}$ In Canada, some provinces have implemented pay-for-performance incentives, particularly for primary care physicians, ${ }^{2-6}$ despite the equivocal and limited nature of the evidence supporting them. In September 2011, the government of Ontario introduced bonus payments to encourage psychiatrists to provide rapid access to patients within 30 days of discharge after a psychiatric hospital admission and for 6 months after a suicide attempt. These are both high-risk periods for adverse events, and there is evidence that access to timely follow-up care may reduce the risk. ${ }^{7}$ By encouraging the delivery of follow-up care, the objective of these incentives was to help reduce the risk of deterioration, early readmission to hospital and possibly further suicide attempts. Implementation of these incentives followed similar attempts by pro- vincial governments to improve the supply of services to high-risk patients in primary care settings. ${ }^{2,3,5,6}$ In particular, the government of Ontario has introduced incentives to encourage primary care physicians to roster patients with severe mental illness. In British Columbia, incentives have been implemented to encourage primary care physicians to create mental health care plans in collaboration with patients with a diagnosed mental illness. ${ }^{4}$

In this study, we investigated whether psychiatrists changed their practice patterns in response to the September 2011 incentives, and whether patients at high risk had better access to psychiatrists. Our research questions were as follows: What is the effect of financial incentives on psychiatrist supply of community-based mental health and addiction care after discharge from hospital or after a suicide attempt? Can financial incentives increase access to community-based psychiatric care for patients after discharge or after a suicide attempt? 


\section{Methods}

\section{Setting}

This longitudinal study was conducted in Ontario, where, in September 2011, the provincial government introduced 3 incentive payments to encourage the delivery of community-based psychiatric care. The first payment incentive (billing code K187) pays psychiatrists a $15 \%$ premium on specified service codes for providing outpatient care within 30 days after discharge from a psychiatric hospital admission. The second incentive (billing code K188) pays psychiatrists a $15 \%$ premium for specified services delivered during the 180 days after a suicide attempt. The third incentive (billing code K189) pays psychiatrists an annual $\$ 200$ fee for each patient for whom they provide follow-up within the community in the 4-week period after discharge from a psychiatric hospital admission.

\section{Data sources}

We used administrative data collected by the Ontario Ministry of Health and Long-Term Care and shared, via contractual agreement, with the Institute for Clinical Evaluative Sciences (ICES). These data included information on physician and practice characteristics, physician claims, patient characteristics, admissions to designated psychiatric hospital beds, emergency department visits and suicide attempts. We also used census data to obtain geographic (e.g., rurality measured using the Rurality Index of Ontario ${ }^{8}$ ) and socioeconomic variables. These data sets were linked using unique encoded identifiers and analyzed at ICES. Further details on the databases can be found in Appendix 1 (available at www.cmaj.ca/ lookup/suppl/doi:10.1503/cmaj.160816/-/DC1).

The study period was September 2009 to August 2014. We captured monthly observations on 3 distinct cohorts over this period. The first cohort consisted of all practising psychiatrists in Ontario, except for those who did not appear both before and after implementation of the incentives. The second and third cohorts captured all patients with discharge from a psychiatric hospital admission and all patients with an emergency department visit for a suicide attempt during the study period, respectively. We excluded patients under 16 years of age (because few cases of severe mental illness are diagnosed before this age), those who were not eligible for public health care insurance, those who were not Ontario residents and those who had missing information on key variables. We treated observations on the same patient within a 30-day period as a single event, and used only the final observation during that period.

\section{Outcomes}

For our analysis, we considered 2 outcomes, at the levels of psychiatrists and patients, respectively. At the psychiatrist level, we estimated whether implementation of the incentives resulted in a change in the monthly rates of incentive-eligible services provided after hospital discharge or after a suicide attempt. At the patient level, we estimated whether implementation of the incentives resulted in a change in the likelihood of receiving an incentive-eligible service from a psychiatrist after discharge or after a suicide attempt. An incentive-eligible service was defined as having been provided within 30 days after hospital discharge or within 180 days after a suicide attempt, where billing codes eligible for an incentive payment were applied by the physician.

\section{Covariables}

Our main covariables of interest were the level change in the mean monthly number of visits following implementation of the incentives and the change in the slope (rate of change) in the monthly trend following implementation of the incentives. ${ }^{9}$ We also estimated the slope of the monthly trend before implementation of the incentives.

\section{Statistical analysis}

Because the incentives were implemented simultaneously for all psychiatrists in Ontario, and because no suitable comparison group could be generated with provincial data, we used an interrupted time-series design. For both the psychiatrist- and patient-level analyses, we aggregated the outcomes by generating monthly averages, and estimated the outcomes using a linear time-series model (further details are provided in Appendix 1). We used a Portmanteau (Q) test for stationarity of the trend to validate the model. ${ }^{10}$ For both levels of analysis, we calculated confidence intervals $(\mathrm{Cls})$ using bootstrapped standard errors.

At the psychiatrist level, we stratified psychiatrists into quintiles according to the quantity of incentive-eligible services provided in the pre-incentive period. This allowed us to determine whether the incentives had differential effects on psychiatrists who supplied higher quantities of eligible services in the preincentive period. We also estimated the psychiatrist-level outcomes using individual-level data and an estimator for a count outcome with overdispersion. This allowed us to control for a number of time-varying covariables and unobserved psychiatrist characteristics (Appendix 1). ${ }^{11,12}$ This alternative specification did produce material changes to our results. Thus, our main findings report the results of the linear model.

\section{Ethics approval}

The study was approved by the institutional review board at Sunnybrook Health Sciences Centre.

\section{Results}

Our sample included 1921 psychiatrists (Figure 1), who were followed over a 60-month period (for a total of 111924 monthly observations). Compared with the general psychiatrist population, the providers of the highest quantities of eligible visits in the pre-incentive period were less likely to be women $(28.7 \% \mathrm{v}$. $38.7 \%$ ), less likely to be trained in Canada (51.7\% v. $61.9 \%$ ) and more likely to be practising in rural areas (Rurality Index of Ontario $>0,38.5 \%$ v. $21.9 \%$ ) (Table 1).

At the patient level, our sample included 304574 patients who had been discharged after a psychiatric hospital admission and 78375 patients with a previous suicide attempt. In the pre-incentive period, patients with at least 1 visit to a psychiatrist in the 30 days after discharge tended to be women ( $54 \%$ v. $48 \%$ ), tended to be 
younger (41 yr v. 48 yr), and received greater annual primary care mental health billings (16.6 v. 12.7) and greater annual psychiatrist billings (51.0 v. 13.7) relative to those without a visit (Appendix 2, available at www.cmaj.ca/lookup/suppl/doi:10.1503/cmaj $.160816 /-/ D C 1)$. Also in the pre-incentive period, patients with at least 1 visit to a psychiatrist in the 180 days after a suicide attempt tended to be women (62\% v. 52\%) and received greater annual primary care mental health billings ( 14.9 v. 5.2 ) and greater annual psychiatrist billings (27.6 v. 1.9) (Appendix 3, available at www. cmaj.ca/lookup/suppl/doi:10.1503/cmaj.160816/-/DC1).

We found that the average quantity of monthly visits per psychiatrist provided after discharge decreased after the introduction of the payment incentives (from 1.50 to 1.43), as did the quantity of monthly visits provided after a suicide attempt (from 1.35 to 1.23 ) (Table 2 ).

The results of our interrupted time-series analysis (Table 2) suggest that there was no immediate effect of the incentives on the quantity of visits supplied to patients after hospital discharge (mean change in visits per month per psychiatrist $0.0099,95 \% \mathrm{Cl}$ -0.0989 to 0.1206 ) or after a suicide attempt (mean change $-0.0910,95 \% \mathrm{Cl}-0.1885$ to 0.0026 ). There was also no change in the slope of the monthly trend for visits after hospital discharge (0.0032, $95 \% \mathrm{Cl}-0.0035$ to 0.0095$)$. There was a small increase in the monthly trend for visits provided after a suicide attempt $(0.0102,95 \% \mathrm{Cl} 0.0045$ to 0.0159$)$, which translated into a postincentive monthly trend of 0.003 more visits per month. These findings are presented graphically in Figure 2.

We also analyzed these data by quintiles, according to the number of eligible visits in the pre-incentive period (Table 2). For psychiatrists who provided the least number of eligible visits in the pre-incentive period (i.e., first to third quintiles), we observed a statistically significant immediate increase in the monthly quantity of visits provided after discharge $(0.0862,95 \% \mathrm{Cl} 0.0506$ to 0.1209$)$ and after a suicide attempt $(0.0697,95 \% \mathrm{Cl} 0.0391$ to 0.1244 ). However, the magnitude of these effects was small (less than 0.1 visits per month per psychiatrist). There was also a small change in the slope of the monthly trend following implementation of the incentives for postdischarge visits $(0.0030,95 \% \mathrm{Cl}$ 0.0006 to 0.0054$)$ and for visits provided after a suicide attempt (0.0056, 95\% Cl 0.0027 to 0.0086$)$.

For psychiatrists who provided the most eligible visits in the pre-incentive period (i.e., fourth and fifth quintiles), we did not observe a statistically significant change in the monthly quantity of visits provided after hospital discharge $(-0.0952,95 \% \mathrm{Cl}$ -0.3211 to 0.1440 ), but did observe a statistically significant immediate decrease in the monthly quantity of visits provided after a suicide attempt $(-0.3075,95 \% \mathrm{Cl}-0.5212$ to -0.1210$)$. There was also no change in the slope of the monthly trend for postdischarge visits, and a small significant change in trend for visits provided after a suicide attempt $(0.0143,95 \% \mathrm{Cl} 0.0015$ to $0.0259)$. However, postdischarge visits displayed a slightly decreasing monthly trend overall after implementation of the incentives.

The findings from our patient-level analysis (Table 3) suggest that the likelihood of receiving an eligible visit after hospital discharge or after a suicide attempt remained static over the study period. Implementation of the incentives had no immediate effect on the probability of a patient seeing a psychiatrist 30 days
Psychiatrist cohort

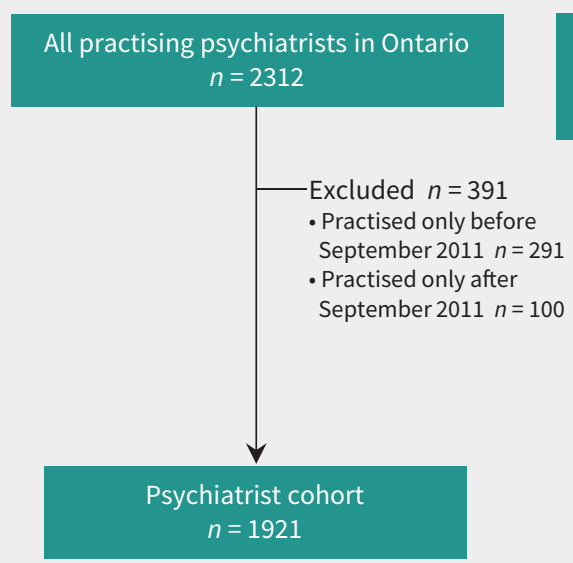

Discharge patient cohort

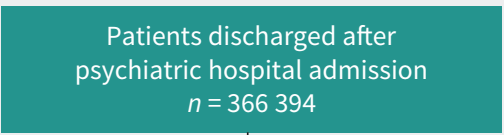

Excluded $n=61820$

- Age $<16$ yr $n=19602$

- Not eligible for public insurance $n=668$

- No Ontario postal code $n=762$

- Missing values $n=101$ - Hospital admission within $30 \mathrm{~d} n=40687$

\section{Discharge patient cohort} $n=304574$
Self-harm patient cohort

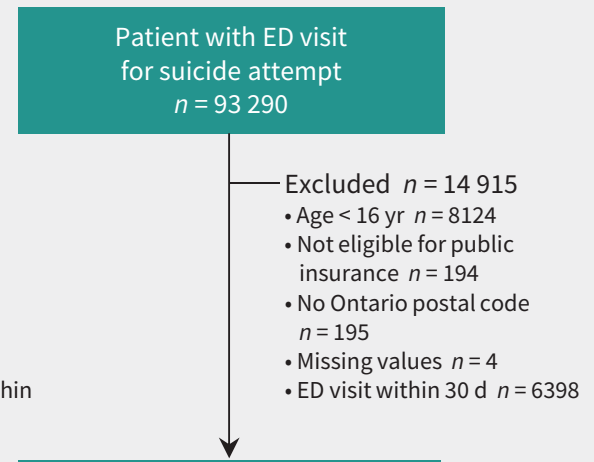

Self-harm patient cohort $n=78375$

Figure 1: Study cohorts. For the psychiatrist cohort, the $n$ values refer to unique psychiatrists. Note: $E D=$ emergency department. 
Table 1: Descriptive statistics for psychiatrist cohort before and after implementation of incentives*

\begin{tabular}{|c|c|c|c|c|c|c|}
\hline \multirow[b]{2}{*}{ Covariable } & \multicolumn{3}{|c|}{ Before incentive $†$} & \multicolumn{3}{|c|}{ After incentive $\ddagger$} \\
\hline & Full sample & $\begin{array}{l}\text { Lowest } \\
\text { quintile§ }\end{array}$ & $\begin{array}{l}\text { Highest } \\
\text { quintile§ }\end{array}$ & Full sample & $\begin{array}{l}\text { Lowest } \\
\text { quintile§ }\end{array}$ & $\begin{array}{l}\text { Highest } \\
\text { quintile§ }\end{array}$ \\
\hline No. of observations & 45024 & 9360 & 9000 & 66900 & 13356 & 13680 \\
\hline Sex, female, \% & $\begin{array}{c}38.7 \\
(38.2 \text { to } 39.1)\end{array}$ & $\begin{array}{c}47.1 \\
\text { (46.0 to } 48.1)\end{array}$ & $\begin{array}{c}28.7 \\
\text { (27.7 to } 29.6)\end{array}$ & $\begin{array}{c}38.9 \\
(38.5 \text { to } 39.3)\end{array}$ & $\begin{array}{c}47.8 \\
(47.0 \text { to } 48.6)\end{array}$ & $\begin{array}{c}28.5 \\
(27.8 \text { to } 29.3)\end{array}$ \\
\hline Age, yr, mean & $\begin{array}{c}54.7 \\
\text { (54.6 to } 54.8)\end{array}$ & $\begin{array}{c}58.3 \\
\text { (58.0 to } 58.5 \text { ) }\end{array}$ & $\begin{array}{c}51.7 \\
\text { (51.5 to } 51.9)\end{array}$ & $\begin{array}{c}56.7 \\
\text { (56.6 to } 56.8 \text { ) }\end{array}$ & $\begin{array}{c}59.8 \\
(59.6 \text { to } 60.0)\end{array}$ & $\begin{array}{c}53.8 \\
(53.7 \text { to } 54.0)\end{array}$ \\
\hline Rural practice, \% & $\begin{array}{c}21.9 \\
\text { (21.5 to } 22.3)\end{array}$ & $\begin{array}{c}13.3 \\
(12.6 \text { to } 14.0)\end{array}$ & $\begin{array}{c}38.5 \\
(37.5 \text { to } 39.5)\end{array}$ & $\begin{array}{c}22.3 \\
\text { (21.9 to } 22.6)\end{array}$ & $\begin{array}{c}13.5 \\
(12.9 \text { to } 14.1)\end{array}$ & $\begin{array}{c}38.9 \\
\text { (38.0 to } 39.7)\end{array}$ \\
\hline Canadian medical graduate, $\%$ & $\begin{array}{c}61.9 \\
\text { (61.4 to } 62.3)\end{array}$ & $\begin{array}{c}70.0 \\
\text { (69.1 to } 70.9)\end{array}$ & $\begin{array}{c}51.7 \\
(50.7 \text { to } 52.7)\end{array}$ & $\begin{array}{c}62.1 \\
(61.7 \text { to } 62.5)\end{array}$ & $\begin{array}{c}71.7 \\
\text { (70.9 to } 72.5 \text { ) }\end{array}$ & $\begin{array}{c}51.2 \\
(50.4 \text { to } 52.1)\end{array}$ \\
\hline Full-time practice, $\%$ & $\begin{array}{c}72.2 \\
(71.8 \text { to } 72.6)\end{array}$ & $\begin{array}{c}48.6 \\
(47.6 \text { to } 49.6)\end{array}$ & $\begin{array}{c}94.1 \\
\text { (93.6 to } 94.6)\end{array}$ & $\begin{array}{c}71.8 \\
\text { (71.4 to } 72.1)\end{array}$ & $\begin{array}{c}49.0 \\
\text { (48.1 to } 49.8)\end{array}$ & $\begin{array}{c}94.1 \\
\text { (93.7 to } 94.5)\end{array}$ \\
\hline No. of outpatients seen/yr & $\begin{array}{c}187.7 \\
(185.6 \text { to } 189.8)\end{array}$ & $\begin{array}{c}53.8 \\
(52.5 \text { to } 55.0)\end{array}$ & $\begin{array}{c}336.8 \\
(330.9 \text { to } 342.6)\end{array}$ & $\begin{array}{c}202.0 \\
(200.2 \text { to } 203.8)\end{array}$ & $\begin{array}{c}57.2 \\
(56.0 \text { to } 58.4)\end{array}$ & $\begin{array}{c}372.4 \\
(367.5 \text { to } 377.3)\end{array}$ \\
\hline No. of outpatient visits/mo & $\begin{array}{c}94.5 \\
\text { (93.7 to } 95.3 \text { ) }\end{array}$ & $\begin{array}{c}56.4 \\
\text { (54.9 to } 57.8 \text { ) }\end{array}$ & $\begin{array}{c}152.4 \\
(150.1 \text { to } 154.6)\end{array}$ & $\begin{array}{c}90.5 \\
\text { (89.8 to } 91.2 \text { ) }\end{array}$ & $\begin{array}{c}53.9 \\
(52.8 \text { to } 55.0)\end{array}$ & $\begin{array}{c}148.1 \\
(145.9 \text { to } 150.2)\end{array}$ \\
\hline $\begin{array}{l}\text { No. of patients seen/yr with } \\
\text { psychiatric hospital admission in } \\
\text { previous year }\end{array}$ & $\begin{array}{c}33.2 \\
(32.7 \text { to } 33.8)\end{array}$ & $\begin{array}{c}2.3 \\
\text { (2.1 to } 2.4 \text { ) }\end{array}$ & $\begin{array}{c}99.7 \\
\text { (97.8 to } 101.6)\end{array}$ & $\begin{array}{c}36.3 \\
\text { (35.9 to } 36.8)\end{array}$ & $\begin{array}{c}3.6 \\
\text { (3.4 to } 3.9)\end{array}$ & $\begin{array}{c}106.0 \\
\text { (104.4 to } 107.5)\end{array}$ \\
\hline
\end{tabular}

\section{Table 2: Effect of the intervention on psychiatrist supply of incentive-eligible visits}

\begin{tabular}{|c|c|c|c|c|c|c|}
\hline \multirow[b]{2}{*}{ Outcome } & \multicolumn{3}{|c|}{ Postdischarge visits/mo per psychiatrist* } & \multicolumn{3}{|c|}{ Post-suicide attempt visits/mo per psychiatrist* } \\
\hline & Full sample & $\begin{array}{l}\text { Q1-Q3 } \\
\text { providers }\end{array}$ & $\begin{array}{l}\text { Q4 and Q5 } \\
\text { providers }\end{array}$ & Full sample & $\begin{array}{l}\text { Q1-Q3 } \\
\text { providers }\end{array}$ & $\begin{array}{l}\text { Q4 and Q5 } \\
\text { providers }\end{array}$ \\
\hline \multicolumn{7}{|l|}{ Mean eligible visits/mo } \\
\hline Before introduction of incentives & $\begin{array}{c}1.50 \\
(1.47 \text { to } 1.53)\end{array}$ & $\begin{array}{c}0.30 \\
(0.29 \text { to } 0.31)\end{array}$ & $\begin{array}{c}3.33 \\
(3.23 \text { to } 3.43)\end{array}$ & $\begin{array}{c}1.35 \\
\text { (1.32 to } 1.38)\end{array}$ & $\begin{array}{c}0.26 \\
(0.25 \text { to } 0.27)\end{array}$ & $\begin{array}{c}3.03 \\
(2.93 \text { to } 3.12)\end{array}$ \\
\hline After introduction of incentives & $\begin{array}{c}1.43 \\
(1.41 \text { to } 1.46)\end{array}$ & $\begin{array}{c}0.42 \\
(0.40 \text { to } 0.44)\end{array}$ & $\begin{array}{c}2.94 \\
(2.85 \text { to } 3.03)\end{array}$ & $\begin{array}{c}1.23 \\
(1.21 \text { to } 1.26)\end{array}$ & $\begin{array}{c}0.40 \\
(0.38 \text { to } 0.43)\end{array}$ & $\begin{array}{c}2.47 \\
(2.40 \text { to } 2.54)\end{array}$ \\
\hline \multicolumn{7}{|l|}{ Model estimates $†$} \\
\hline Pre-incentive trend $\ddagger$ & $\begin{array}{c}-0.0045 \\
(-0.0102 \text { to } 0.0011)\end{array}$ & $\begin{array}{c}-0.0008 \\
(-0.0028 \text { to } 0.0011)\end{array}$ & $\begin{array}{c}-0.0100 \\
(-0.0230 \text { to } 0.0029)\end{array}$ & $\begin{array}{c}-0.0071 \\
(-0.0117 \text { to }-0.0023)\end{array}$ & $\begin{array}{c}-0.0010 \\
(-0.0035 \text { to } 0.0004)\end{array}$ & $\begin{array}{c}-0.0171 \\
(-0.0267 \text { to }-0.0057)\end{array}$ \\
\hline $\begin{array}{l}\text { Change in level after introduction } \\
\text { of incentives§ }\end{array}$ & $\begin{array}{c}0.0099 \\
(-0.0989 \text { to } 0.1206)\end{array}$ & $\begin{array}{c}0.0862 \\
(0.0506 \text { to } 0.1209)\end{array}$ & $\begin{array}{c}-0.0952 \\
(-0.3211 \text { to } 0.1440)\end{array}$ & $\begin{array}{c}-0.0910 \\
(-0.1885 \text { to } 0.0026)\end{array}$ & $\begin{array}{c}0.0697 \\
(0.0391 \text { to } 0.1244)\end{array}$ & $\begin{array}{c}-0.3075 \\
(-0.5212 \text { to }-0.1210)\end{array}$ \\
\hline $\begin{array}{l}\text { Change in trend after } \\
\text { introduction of incentives }\end{array}$ & $\begin{array}{c}0.0032 \\
(-0.0035 \text { to } 0.0095)\end{array}$ & $\begin{array}{c}0.0030 \\
(0.0006 \text { to } 0.0054)\end{array}$ & $\begin{array}{c}0.00008 \\
(-0.0152 \text { to } 0.0147)\end{array}$ & $\begin{array}{c}0.0102 \\
(0.0045 \text { to } 0.0159)\end{array}$ & $\begin{array}{c}0.0056 \\
(0.0027 \text { to } 0.0086)\end{array}$ & $\begin{array}{c}0.0143 \\
(0.0015 \text { to } 0.0259)\end{array}$ \\
\hline Post-incentive trend ${ }^{\star \star}$ & $\begin{array}{c}-0.0013 \\
(-0.0050 \text { to } 0.0020)\end{array}$ & $\begin{array}{c}0.0022 \\
(0.0008 \text { to } 0.0035)\end{array}$ & $\begin{array}{c}-0.0098 \\
(-0.0172 \text { to }-0.0032)\end{array}$ & $\begin{array}{c}0.0030 \\
(-0.0003 \text { to } 0.0062)\end{array}$ & $\begin{array}{c}0.0046 \\
(0.0021 \text { to } 0.0064)\end{array}$ & $\begin{array}{c}-0.0029 \\
(-0.0091 \text { to } 0.0031)\end{array}$ \\
\hline \multicolumn{7}{|c|}{$\begin{array}{l}\text { Note: Q1 to Q5 represent quintiles, where Q1 = lowest quintile and Q5 = highest quintile for the quantity of incentive-eligible services provided in the pre-incentive period. } \\
\text { ^All estimates are presented with } 95 \% \text { confidence intervals. } \\
\text { †Confidence intervals on model estimates were calculated with bootstrap standard errors (using } 1000 \text { replications). All estimates are conditional on other model covariab } \\
\text { reported). } \\
\text { †The monthly change in the mean number of visits before introduction of the incentives. } \\
\text { §The level change in the mean monthly number of visits after introduction of the incentives. } \\
\text { IThe change in the trend for mean monthly number of visits after introduction of the incentives, compared with the monthly trend before introduction of the incentives. } \\
\star \star \text { The monthly change in the mean number of visits after introduction of the incentives. }\end{array}$} \\
\hline
\end{tabular}


after discharge (change in level $-0.0079,95 \% \mathrm{Cl}-0.0223$ to 0.0061 ; change in trend $0.0007,95 \% \mathrm{Cl}-0.0003$ to 0.0016 ) or 180 days after a suicide attempt (change in level $0.0074,95 \% \mathrm{Cl}$ -0.0094 to 0.0366 ; change in trend $0.0006,95 \% \mathrm{Cl}-0.0007$ to $0.0022)$. There was also no change in the slope of the monthly trend of the probability of a postdischarge visit $(0.0007,95 \% \mathrm{Cl}$ -0.0003 to 0.0016$)$ or the probability of a visit after a suicide attempt $(0.0006,95 \% \mathrm{Cl}-0.0007$ to 0.0022$)$. These findings are presented graphically in Figure 3.

To further explore the psychiatrist-level results, we calculated the proportion of psychiatrists who billed the payment incentives, and the proportion of eligible services provided where the incentive payment was used (Table 4). The proportion of psychiatrists who billed the various incentive codes ranged from $8.5 \%$ for $\mathrm{K} 189$ to $23.7 \%$ for $\mathrm{K} 187$. The proportion of eligible services to which an incentive code was applied ranged from $1.35 \%(95 \% \mathrm{Cl}$ $1.26 \%$ to $1.44 \%$ ) for $\mathrm{K} 189$ to $5.50 \%$ (95\% Cl 5.33\% to $5.67 \%$ ) for K187 for all psychiatrists. However, among psychiatrists who billed at least 1 incentive code, these proportions ranged from 95.77\% (95\% Cl 95.20\% to $96.34 \%$ ) for $\mathrm{K} 188$ to $99.96 \%(95 \% \mathrm{Cl}$ $99.91 \%$ to $100.00 \%$ ) for K189. These results suggest that a small proportion of psychiatrists billed the incentives, and that those who used the incentive codes did so for a majority of their eligible visits.

\section{Interpretation}

The 3 incentives implemented in Ontario did not have a meaningful effect on psychiatrist behaviour or on the likelihood that patients would receive psychiatric care after discharge from hospital or after a suicide attempt. The rates of follow-up care and the quantity of follow-up services provided remained static over the study period.

We propose 2 explanations for these findings. The first concerns the design and implementation of the incentives. Using the average fee for eligible services, the incentive payment per eligible service was about $\$ 30$, which may not have been large enough to alter psychiatrist behaviour or to encourage psychiatrists to incorporate the incentive codes into their usual billing routines. A similar study of Ontario's diabetes incentive payment for primary care physicians also showed minimal improvements in care, ${ }^{2}$ and, like us, that study's authors suggested that the result may have been due to the size of the incentive payment. ${ }^{2}$ There is some evidence that the size of the incentive must be large enough to achieve behaviour response. ${ }^{13-19}$ One study surveyed managers of health management organizations in the United States about how primary care physicians responded to financial incentives, and showed that bonuses of at least $5 \%$ of income would be sufficient to achieve behaviour change. ${ }^{15}$ Other research has identified several factors influencing the impact of pay for performance, including incentive size, duration, group versus individual incentives and case-mix risk-adjustment techniques. ${ }^{1,13,17,18}$ The literature also suggests that communication and consultation can be key factors in the success of pay-forperformance interventions, in particular, the involvement of providers in the design of performance measures and incentives. ${ }^{13,18}$
It is possible that many Ontario psychiatrists simply did not know that the incentive payments were available.

The second explanation concerns the context in which the incentives were implemented. Kurdyak and colleagues ${ }^{20}$ described great variation in the way psychiatric services are delivered in Ontario. Psychiatrists practising in urban areas, such as Toronto, were more likely to see fewer patients, but provided those patients with higher quantities of services. In the current study, we found that psychiatrists practising in urban areas were less likely to provide follow-up care and were less likely to take on newly discharged patients. The effectiveness of financial incentives may be limited for these psychiatrists, particularly if they are satisfied with the level of income they receive from their current practice. There is evidence that once physicians reach a target income, the availability of additional payments will not lead to significant behaviour change. ${ }^{13,21}$ Unfortunately, we do not have access to information on psychiatrists' preferences; further exploration of these

\section{$30 \mathrm{~d}$ after discharge}

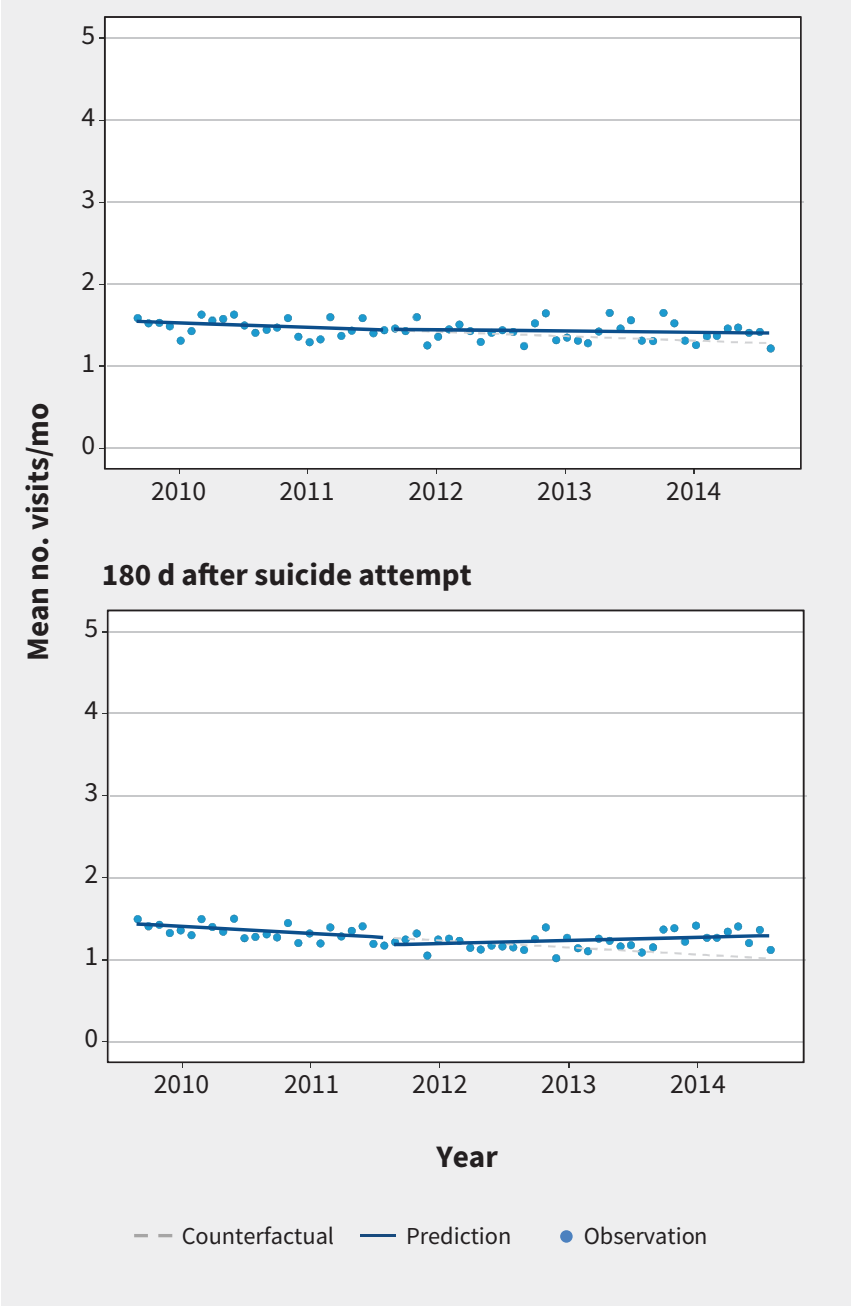

Figure 2: Mean monthly number of eligible psychiatrist visits: 30 days after discharge from psychiatric hospital admission (top) and 180 days after a suicide attempt (bottom). 
Table 3: Effect of the intervention on the probability of visiting a psychiatrist

Probability of visiting psychiatrist $(95 \% \mathrm{CI})^{\text {* }}$

\section{Model estimate}

Pre-incentive trend $\dagger$

Change in level after introduction of incentivesł

Change in trend after introduction of incentives§

Post-incentive trend

Note: $\mathrm{Cl}=$ confidence interval.

${ }^{*}$ Cls on model estimates were calculated with bootstrap standard errors (using 1000 replications).

tThe monthly change in the probability of a visit before introduction of the incentives.

$\ddagger$ The level change in the probability of a visit after introduction of the incentives.

$\S$ The change in the trend for probability of a visit after introduction of the incentives, compared with the monthly trend before introduction of

the incentives.

IThe monthly change in the probability of a visit after introduction of the incentives.

\section{$180 \mathrm{~d}$ after suicide attempt}

$0.0002(-0.0013$ to 0.0012$)$

$0.0074(-0.0094$ to 0.0366$)$

$0.0006(-0.0007$ to 0.0022$)$

0.0009 (0.0001 to 0.0015$)$

\section{$30 \mathrm{~d}$ after discharge}

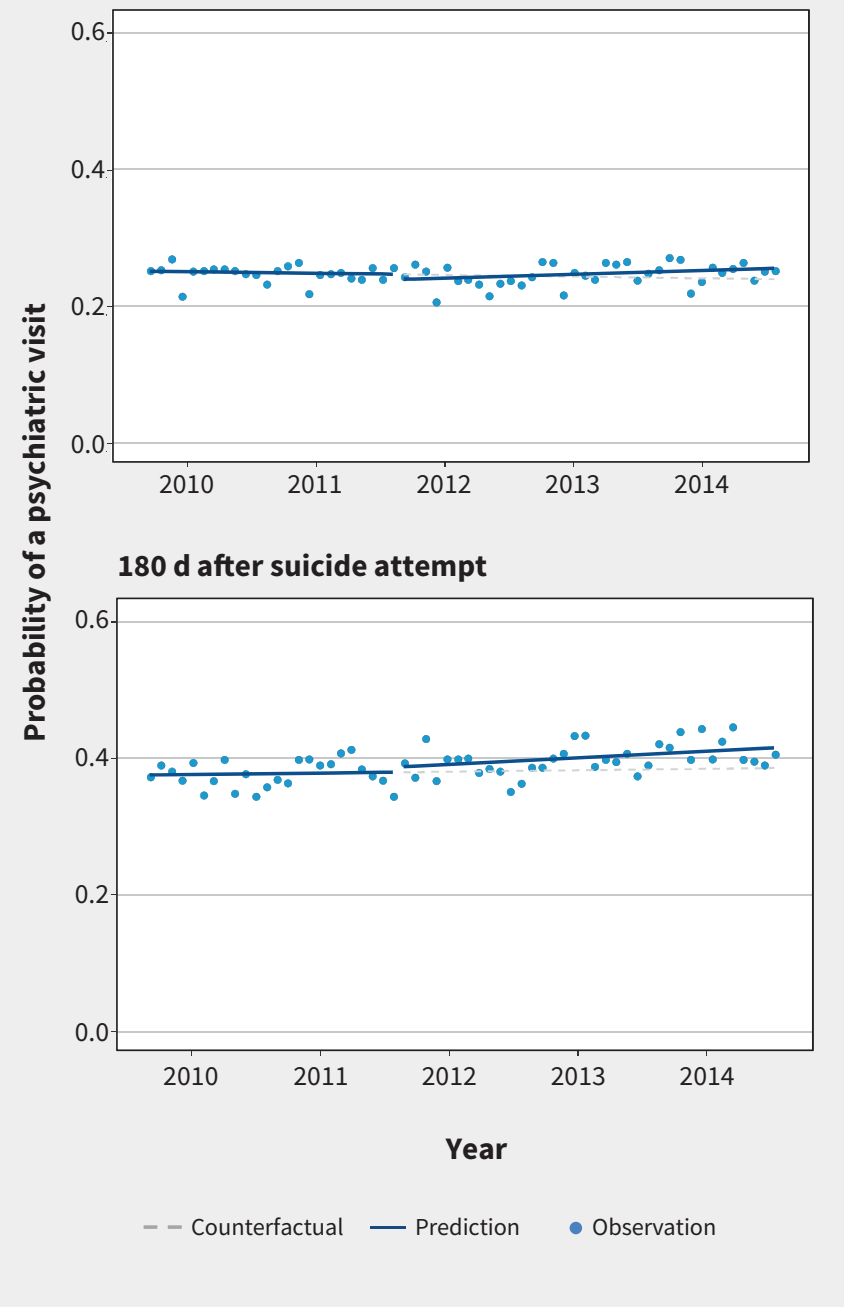

Figure 3: Probability of a psychiatric visit: 30 days after discharge from a psychiatric hospital admission (top) and 180 days after a suicide attempt (bottom). preferences and views concerning payment could be the topic of future research.

Our results are in line with existing research. Using similar data, previous evaluations of pay for performance for primary care physicians in Canada have yielded mixed results ${ }^{2,6}$ or shown no effects. ${ }^{3,4}$ The proportion of physicians billing the incentives was lower in our case than in other similar studies ${ }^{2,3,6}$ but was similar to the proportion of primary care physicians billing certain of the incentives in the study by Li and colleagues. ${ }^{6}$

Although pay for performance has been widely implemented, there is equivocal and limited evidence regarding its effectiveness. ${ }^{19,22-27}$ A systematic review of the effect of financial incentives for primary care physicians found modest or no effects. ${ }^{23}$ Lavergne and colleagues ${ }^{4}$ evaluated pay-for-performance payments for primary care physicians in $\mathrm{BC}$ and found that incentives had no effect on visits or continuity of care, but were associated with increased rates of hospital admission. Several studies of primary care pay for performance for cancer screening and diabetes management have been conducted in Ontario, ${ }^{2,3,6}$ with similarly equivocal results. For instance, Kiran and colleagues ${ }^{3}$ evaluated incentives for cancer screening for primary care physicians in Ontario and found no effect on cancer screening rates, which were already increasing before implementation of the incentives. Li and colleagues, ${ }^{6}$ in an evaluation of a series of preventive care pay-for-performance incentives for primary care physicians in Ontario, found that a small proportion of eligible physicians billed these claims (between $2 \%$ and $47 \%$ in most periods) and that the introduction of the incentives had modest effects on preventive care.

Most work thus far has been on primary care incentives, whereas little work has investigated pay for performance for mental health and addiction services in general or on psychiatrist behaviour specifically. Gutacker and colleagues ${ }^{28}$ evaluated whether incentives in the Quality for Outcomes Framework in the United Kingdom led to reductions in hospital admission for individuals with severe mental illness. Using data on a sample of 8234 primary care physician practices, 
Table 4: Number of psychiatrists who billed incentives and proportion of eligible visits with incentive code

\begin{tabular}{lccc}
$\begin{array}{l}\text { Incentive } \\
\text { code }\end{array}$ & $\begin{array}{c}\text { No. (\%) of psychiatrists } \\
\text { who billed code } \\
\boldsymbol{n = 1 9 2 1}\end{array}$ & All psychiatrists & $\begin{array}{c}\text { Group; \% of eligible visits billed (95\% Cl) } \\
\mathbf{2}\end{array}$ \\
\hline K187 incentive code
\end{tabular}

Note: $\mathrm{Cl}$ = confidence interval, $\mathrm{K} 187$ = incentive code for "acute post-discharge community psychiatric care," K188 = incentive code for "high risk community psychiatric care," K189 = incentive code for "urgent community psychiatric follow-up."

they found that the achievement of quality indicators for mental health and addiction care was associated with higher rates of psychiatric admission. In the US, Unützer and colleagues ${ }^{29}$ evaluated a pay-for-performance incentive that was part of a larger quality improvement intervention for a state-funded community health plan for low-income adults with physical or mental health conditions ( $n=1673$ patients before and $n=$ 6304 patients after implementation of the incentive). These authors found that the pay-for-performance payment was associated with improvements in timely follow-up and in time to depression improvement. Two US studies ${ }^{30,31}$ found that incentives for psychiatrists had positive effects on quality measures and access. Using a cluster randomized trial design (including 105 therapists and 986 patients), the authors found that a pay-for-performance intervention to improve treatment for adolescents with substance use disorders had a positive effect on the use of evidence-based treatment, but no effect on patient outcomes. ${ }^{31}$

\section{Limitations}

This study had some limitations. First, we did not have a comparison group and relied on time-series variation to assess the effect of the payment incentives. It is possible that in the absence of these incentive payments, there would have been a discontinuity in the trends; however, we believe this is unlikely, given the stability of the observed trends. Second, our study suffered from censoring. Psychiatrists drop out of practice for unknown reasons (e.g., parental leave, leaving the province), and we were unable to control for this factor with the available data.

\section{Conclusion}

We found that incentives to encourage community-based psychiatric follow-up care were not associated with improvements in access to care or changes in physician behaviour. Although we focused on the situation in Ontario, our findings will be important for policy-makers in all high-income countries where the use of payment incentives to improve health care delivery is an important concern. Our results do not necessarily suggest that financial incentives should be abandoned as a tool to improve the delivery of health care services, but they do indicate that careful thought should be given to the design of such incentives and the context in which they are implemented. For instance, further research using a mixed-methods design could explore why psychiatrists were not responsive to these particular incentives, and whether specific features of the Ontario context were contributing factors. As it stands, the provincial investment in these incentive payments has not produced any discernible value, and psychiatrists are not responding.

\section{References}

1. Cashin C, Chi YL, Smith PC, et al., editors. Paying for performance in health care: implications for health system performance and accountability. Berkshire (UK): Open University Press, McGraw Hill Education; 2014

2. Kiran T, Victor JC, Kopp A, et al. The relationship between financial incentives and quality of diabetes care in Ontario, Canada. Diabetes Care 2012; 35:1038-46.

3. Kiran T, Wilton AS, Moineddin R, et al. Effect of payment incentives on cancer screening in Ontario primary care. Ann Fam Med 2014;12:317-23.

4. Lavergne MR, Law MR, Peterson S, et al. A population-based analysis of incentive payments to primary care physicians for the care of patients with complex disease. CMAJ 2016;188:E375-83.

5. Kantarevic J, Kralj B. Link between pay for performance incentives and physician payment mechanisms: evidence from the diabetes management incentive in Ontario. Health Econ 2013;22:1417-39.

6. Li J, Hurley J, DeCicca P, et al. Physician response to pay-for-performance: evidence from a natural experiment. Health Econ 2014;23:962-78.

7. Vigod SN, Kurdyak PA, Dennis CL, et al. Transitional interventions to reduce early psychiatric readmissions in adults: systematic review. $\mathrm{Br} J$ Psychiatry 2013;202:187-94.

8. Kralj B. Measuring "rurality" for purposes of health-care planning: an empirical measure for Ontario. Ont Med Rev 2000;67:33-52.

9. Wagner AK, Soumerai SB, Zhang F, et al. Segmented regression analysis of interrupted time series studies in medication use research. J Clin Pharm Ther 2002;27:299-309.

10. Ljung GM, Box GEP. On a measure of lack of fit in time series models. Biometrika 1978;65:297-303.

11. Allison PD. Quantitative applications in the social sciences. Vol. 160: Fixed effects regression models. Thousand Oaks (CA): Sage Publications; 2009.

12. Cameron AC, Trivedi PK. Microeconometrics: methods and applications. New York: Cambridge University Press; 2005.

13. Eijkenaar F. Key issues in the design of pay for performance programs. Eur $J$ Health Econ 2013;14:117-31.

14. Mullen KJ, Frank RG, Rosenthal MB. Can you get what you pay for? Pay-forperformance and the quality of healthcare providers. Rand J Econ 2010; 41:64-91.

15. Hillman AL, Pauly MV, Kerman K, et al. HMO managers' views on financial incentives and quality. Health Aff (Millwood) 1991;10:207-19.

16. Hillman AL, Ripley K, Goldfarb N, et al. Physician financial incentives and feedback: failure to increase cancer screening in Medicaid managed care. Am J Public Health 1998;88:1699-701.

17. Maynard A. The powers and pitfalls of payment for performance. Health Econ 2012;21:3-12.

18. Bremer RW, Scholle SH, Keyser D, et al. Pay for performance in behavioral health. Psychiatr Serv 2008;59:1419-29. 
19. Armour BS, Pitts MM, Maclean R, et al. The effect of explicit financial incentives on physician behavior. Arch Intern Med 2001;161:1261-6.

20. Kurdyak P, Stukel TA, Goldbloom D, et al. Universal coverage without universal access: a study of psychiatrist supply and practice patterns in Ontario. Open Med 2014;8:e87-99.

21. Rizzo JA, Zeckhauser RJ. Reference incomes, loss aversion, and physician behavior. Rev Econ Stat 2003;85:909-22.

22. Town R, Kane R, Johnson P, et al. Economic incentives and physicians' delivery of preventive care: a systematic review. Am J Prev Med 2005;28:234-40.

23. Scott A, Sivey $P$, Ait Ouakrim D, et al. The effect of financial incentives on the quality of health care provided by primary care physicians. Cochrane Database Syst Rev 2011;(9):CD008451.

24. Van Herck P, De Smedt D, Annemans L, et al. Systematic review: effects, design choices, and context of pay-for-performance in health care. BMC Health Serv Res 2010;10:247.

25. Christianson JB, Leatherman S, Sutherland K. Lessons from evaluations of purchaser pay-for-performance programs: a review of the evidence. Med Care Res Rev 2008;65(6 Suppl):5S-35S.
26. Conrad DA, Christianson JB. Penetrating the "black box": financial incentives for enhancing the quality of physician services. Med Care Res Rev 2004;61(3 Suppl):37S-68S.

27. Gillam SJ, Siriwardena AN, Steel N. Pay-for-performance in the United Kingdom: impact of the quality and outcomes framework: a systematic review. Ann Fam Med 2012;10:461-8.

28. Gutacker N, Mason AR, Kendrick T, et al. Does the quality and outcomes framework reduce psychiatric admissions in people with serious mental illness? A regression analysis. BMJ Open 2015;5:e007342.

29. Unützer J, Chan YF, Hafer E, et al. Quality improvement with pay-for-performance incentives in integrated behavioral health care. Am J Public Health 2012; 102:e41-5.

30. Garner BR, Godley SH, Bair CML. The impact of pay-for-performance on therapists' intentions to deliver high-quality treatment. J Subst Abuse Treat 2011;41:97-103.

31. Garner BR, Godley SH, Dennis ML, et al. Using pay for performance to improve treatment implementation for adolescent substance use disorders: results from a cluster randomized trial. Arch Pediatr Adolesc Med 2012;166:938-44.

\section{Competing interests: None declared.}

This article has been peer reviewed.

Affiliations: Institute for Mental Health Policy Research (Rudoler, de Oliveira, Cheng, Kurdyak), Centre for Addiction and Mental Health; Mental Health and Addictions Research Program (Rudoler, de Oliveira, Cheng, Kurdyak), Institute for Clinical Evaluative Sciences; Department of Psychiatry, Faculty of Medicine (Kurdyak) and Institute of Health Policy, Management and Evaluation (Rudoler, de Oliveira, Cheng), University of Toronto, Toronto, Ont.

Contributors: David Rudoler oversaw the data collection, conducted the statistical analysis, and drafted and revised the paper. Claire de Oliveira oversaw the data collection, provided advice on statistical analysis, and contributed to the final draft and revision of the manuscript. Joyce Cheng collected and cleaned the data for analysis and contributed to the initial draft and revision of the manuscript. Paul Kurdyak provided project oversight, advice on the data collection process and the statistical analysis, and guidance on interpretation of the findings; he also contributed to the initial draft and revision of the manuscript. All of the authors gave final approval of the version to be published and agreed to be accountable for all aspects of the work.

Funding: No direct funding was received for this project. David Rudoler's postdoctoral work is supported by the Centre for Addiction and Mental Health, the Institute for Clinical Evaluative Sciences and the University of Toronto.
Disclaimer: This study was supported by the Institute for Clinical Evaluative Sciences (ICES), which is funded by an annual grant from the Ontario Ministry of Health and LongTerm Care (MOHLTC). In addition, parts of this material are based on data and information compiled and provided by the Canadian Institute for Health Information. The opinions, results and conclusions reported in this paper are those of the authors and are independent from the funding sources. No endorsement by ICES or the Ontario MOHLTC is intended or should be inferred.

Accepted: July 20, 2017

Correspondence to: David Rudoler, david. rudoler@uoit.ca 